\title{
Distribution, eco-climatic characterisation, and potential growing regions of Annona cherimola Mill. (Annonaceae) in Mexico
}

Jesús Rubén Rodríguez-Núñez ${ }^{1}$; Eduardo Campos-Rojas²; Jorge Andrés-Agustín ${ }^{3}$; Irán Alia-Tejacal ${ }^{4}$; Santo Ángel Ortega-Acosta ${ }^{5}$; Vicente Peña-Caballero ${ }^{1}$; Tomás Jesús Madera-Santana ${ }^{6}$; and Carlos Alberto Núñez-Colín*

\begin{abstract}
The cherimoya (Annona cherimola Mill.) is a fruit crop with worldwide commercial importance. However, its distribution and potential growing regions of cherimoya are not defined for Mexico. That is why, this research aims to map the natural distribution of cherimoya and different eco-climatic regions where it is grown in Mexico as well as to map the climatic adaptability with the current climate and a prospection with the climate change scenario, all by different models of GIS. The general distribution model of cherimoya in Mexico showed that it had a chance to find cherimoya "in a natural way" in the biogeographic provinces Trans-Mexican Volcanic Belt, Sierra Madre del Sur and Highlands of Chiapas. Three eco-climatic groups were found in the distribution of cherimoya that corresponded to climates $C(m)(w),(A) C\left(e^{\prime}\right)$, and $(A) C(e)$, respectively. Where the group with climate $(A) C(e)$ had the most restricted distribution. The potential growing regions of excellent adaptation of cherimoya were found in the biogeographic provinces of Trans-Mexican Volcanic Belt, Sierra Madre Occidental, Sierra Madre Oriental, Sierra Madre del Sur and Highlands of Chiapas. Finally, based on eco-crop modelling, it is concluded that climate change will not greatly affect areas of excellent adaptation of cherimoya in Mexico.
\end{abstract}

Keywords: Geographic Information Systems; Eco-Climatic Characterisation; Potential Growing Regions; Distribution Modelling; Annonaceae.

1 Programa de Biotecnología, Universidad de Guanajuato. Mutualismo \#303, Col. La Suiza, Celaya, Guanajuato, 38060, México. 2 Departamento de Fitotecnia, Universidad Autónoma Chapingo. Km 38.5 Carretera México-Texcoco, Chapingo, Texcoco, México, 56230, México.

3 Centro Regional Universitario Centro Occidente, Universidad Autónoma Chapingo. Periférico Paseo de la República \#1000, Col. Lomas del Valle, Morelia, Michoacán, 58170, México.

4 Facultad de Ciencias Agropecuarias, Universidad Autónoma del Estado de Morelos. Av. Universidad \#1001, Col. Chamilpa, Cuernavaca, Morelos, 62210, México.

5 Facultad de Ciencias Agropecuarias y Ambientales, Universidad Autónoma de Guerrero. Carretera Iguala-Teloloapan S/N, Col. Ignacio Manuel Altamirano, Iguala de la Independencia, Guerrero, 40040, México.

6 Centro de Investigación en Alimentación y Desarrollo, A.C. Antigua Carretera a La Victoria. Km. 0.6 Hermosillo, Sonora, 83304 México.

* Corresponding author $\bowtie$. E-mail address: JRRN (jesus.rodriguez@ugto.mx), ECR (educamro55@gmail.com), IAT (iran.alia@uaem.mx), JAA (aajorge2000@yahoo.com.mx), SAOA (ortega.santo@colpos.mx),VPC (vicente.caballero@ugto.mx), TJMS (madera@ciad.mx), CANC (carlos.nunez@ugto.mx). 


\section{SIGNIFICANCE STATEMENT}

We elucidate the different climates where cherimoya grows in Mexico and modelling of the potential regions where cherimoya can be cultivated, including a global climate change scenario. This work is the first approach to conserve the cherimoya genetic resources for Mexico.

\section{INTRODUCTION}

The family Annonaceae consists of near 108 genera and more than 2400 species, being one of the families that more contribute to the biodiversity of a lot of tropical and subtropical regions around the world (Chatrou et al. 2012). Within these genera outstand the genus Annona, which has species with horticultural interest mainly in the neotropics. Where most of the species of this genus grow in tropical climates and some of them in subtropical regions, like the cherimoya (Annona cherimola Mill.) (Segura et al. 2012).

Mexico is considered a megadiverse country, mainly in its flora (Rzedowski 1993), and in the American continent is perhaps the country with the greatest number of endemism registered (Villaseñor 2003). Because of that, a great interest of the Mexican scientific community to study and to characterize its genetic resources was generated, among them the related to the genus Annona; thus groups of research about this genus was generated as the Red Mexicana de Anonáceas - Mexican Annonaceae Network- (Segura et al. 2012; Andrés-Agustín and Segura Ledesma, 2014; Andrés-Agustín 2015). Where cherimoya (Annona cherimola Mill.) is one of the most studied species among Annonaceae species in Mexico because of its high horticultural potential (Agustín 1999; Andrés-Agustín 2002; Domínguez and Castañeda 2002). Cherimoya is the second important Annonaceae fruit crop in Mexico with 36 harvested hectares and 247.3 ton of production and a value of production of US $\$ 76,162.80$ for 2019 (SIAP, 2020). Besides the current hypothesis by Larranaga et al. (2017) about the Mesoamerican origin of this species, notwithstanding the archaeological remains and the former hypothesis about its South American origin, specifically Andean (Pozorsky and Pozorsky 1997; Bonavia et al. 2004).

It explains why it is the priority the study of this species in Mexico can make good management of the cherimoya's genetic resources. To start planning about the conservation and collect of germplasm as well as its characterization and evaluation it is important to know its distribution and the different climatic variation where cherimoya grows; furthermore, to identify the potential growing regions and the possible variation because of the climatic change (Zagaja 1988). All these studies can be obtained using diverse methods of Geographic Information Systems - GIS(Jones et al. 2002; Guarino et al. 2002; Núñez-
Colín and Goytia-Jiménez 2009; Hijmans et al. 2012; Scheldeman and van Zonneveld 2011; Núñez-Colín et al. 2017). In the case of cherimoya, there are not specialized studies about this subject in Mexico, although there are for Andean regions (van Zonneveld et al. 2012) and the information about its distribution is dispersed. That is why, this research aims to generate maps of the natural distribution of cherimoya (Annona cherimola Mill.) in Mexico and the different eco-climatic regions where it grows (Jones et al. 2002) as well as generating maps of climatic adaptability in the country with the current climate and with a prospection according to estimated climatic change for 2050 (Scheldeman and van Zonneveld 2011) by means several GIS methods.

\section{MATERIAL AND METHODS}

Passport data of SNIB-CONABIO database (CONABIO 2015; 363 passport data, Supplementary table 1) and the Tropicos.org database (Missouri Botanical Garden 2017; 108 passport data) were used; besides, the registered optimal climatic data of cherimoya in the FAO database (FAO 2007) was used. All data formed the sources of information for the cabinet analyses.

Two different analyses based on GIS were being done. The first was made in the software Floramap 1.03 (Jones and Gladkov 1999), which consist to make probabilistic maps of the general natural distribution and the distribution of different eco-climatic regions where cherimoya grows based on a cluster analysis of the accessions that grow in different eco-climatic regions. The probability maps were calculated without weighted, that means, all the coefficients to evaluated climatic variables were equal to one. The transformation of the rain data - to match it with the temperature scale - Power Rain A transform was used with a coefficient of 0.1. Moreover, eight principal components were used, which explained $96.12 \%$ of the total variance (Jones and Gladkov 1999; Jones et al. 2002). All probabilistic maps in Floramap were calculated with a minimal probability of $75 \%$ to locate the species. The resolution for this analysis was 10 minutes of latitude per 10 minutes of longitude.

The second analysis was done with the software DIVA-GIS version 7.5 (Hijmans et al. 2012) to make models of adequate growing regions of cherimoya. It is considered two scenarios, first - called current potential growing regions $(\mathrm{CPGR})$ - real climatic data of 
Table 1. Assumed parameters in the Eco-Crop model for cherimoya (Annona cherimola Mill).

\begin{tabular}{cc}
\hline Parameter & Value \\
\hline Minimal growing season & 240 days \\
Maximal growing season & 270 days \\
Killing temperature & $1{ }^{\circ} \mathrm{C}$ \\
Minimal temperature (No damages) & $7{ }^{\circ} \mathrm{C}$ \\
Optimal minimal temperature & $17{ }^{\circ} \mathrm{C}$ \\
Optimal maximal temperature & $25{ }^{\circ} \mathrm{C}$ \\
Maximal temperature (No damages) & $32{ }^{\circ} \mathrm{C}$ \\
Minimal rainfall & $600 \mathrm{~mm}$ \\
Optimal minimal rainfall & $800 \mathrm{~mm}$ \\
Optimal maximal rainfall & $1200 \mathrm{~mm}$ \\
Maximal rainfall & $2200 \mathrm{~mm}$ \\
\hline
\end{tabular}

50 years of the Wolrdclim database were used; while the second, it was used the CCM3 model that considers the double atmospheric $\mathrm{CO}_{2}$ concentration for modelling the climate change effect - called future potential growing regions (FPGR) - (Govindasamy et al. 2003). The resolution for this analysis was 2.5 minutes of latitude per 2.5 minutes of longitude.

Both models were obtained using the Eco-Crop algorithm (Hijmans et al. 2001; Hijmans and Graham 2006) and the optimal climatic data for adaptation of cherimoya of the FAO database (FAO 2007; Table 1); Both models were also compared to locate the adequate regions to establish in vivo germplasm banks, mother orchards, and evaluation fields of this species with a climate change scenario.

The maps of biogeographic provinces by Morrone et al. (2017) were used for all GIS maps. Morrone et al. (2017) described 14 biogeographic provinces to Mexico: Californian, Baja Californian, Sonoran, Chihuahuan Desert, Tamaulipas, Yucatan Peninsula, Sierra Madre Occidental, Sierra Madre Oriental, the Trans-Mexican Volcanic Belt, Balsas Basin, Sierra Madre del Sur, Pacific Lowlands, Veracruzan, and Chiapas Highlands (Figure 1).

\section{RESULTS AND DISCUSSION}

\section{Distribution in a natural way}

The modelling of the distribution in natural ways of cherimoya in Mexico showed that there are high possibilities to find cherimoya in centre, south and south-eastern Mexico. The provinces with the highest probability to find germplasm $(>90 \%)$ were the Trans-Mexican Volcanic Belt, Sierra Madre del Sur, and Chiapas Highlands (Figure 2), which are mountainous temperate climate provinces. Provinces between 75 and $90 \%$ of probability to find germplasm were Veracruzan, Yucatan Peninsula, south of Sierra Madre Occidental, and centre and south of Sierra
Madre Oriental (Figure 2), where two first provinces have transitional climates and others are mountainous temperate climate provinces.

The distribution results (Figure 2) agree with the reported regions by Segura et al. (2012) although these authors showed some regions in the north central of the country in these authors called as their group 1, the group of which its distribution is the northern region of central Mexico, which did not find in this research.

\section{Eco-climatic characterization}

The considered accessions in this research were divided into three eco-climatic groups (Figure 3), which showed different distributions and adaptation climates in Mexico that could be associated with the presence of three different genetic pools, which can be useful into breeding programs. In different environmental conditions, the populations and the genotypes could have genetic differences in their adaptations to these environments (Dobzhansky, 1970).

A possible practical implication of this information in breeding programs is to develop hybrid cultivars considering as parents, individuals from different genetic pools because they have higher probabilities to obtain heterosis in this cross (Wright, 1978). The climograms of the three groups (Figure 4A, 4, 4C) showed different climatic patterns.

The cluster 1 had an average elevation of $2281.6 \mathrm{~m}$ above sea level (masl). Besides, it showed the fewest mean temperature of the three groups (Figure 4D) with a mean temperature of $14.7^{\circ} \mathrm{C}$ (Figure $4 \mathrm{~A}$ ), a temperature differential (maximal temperature minus minimal temperature) between 11.4 and $15{ }^{\circ} \mathrm{C}$ (Figure $4 \mathrm{E})$. This cluster showed the minimal temperature of the coldest month was $5{ }^{\circ} \mathrm{C}$ (Figure $4 \mathrm{~A}$ ) and maximal temperature of the warmest month was $23.8^{\circ} \mathrm{C}$ (Figure 4A). It also showed an average annual rainfall of $1126.3 \mathrm{~mm}$ (Figure 4A) where the wettest month 


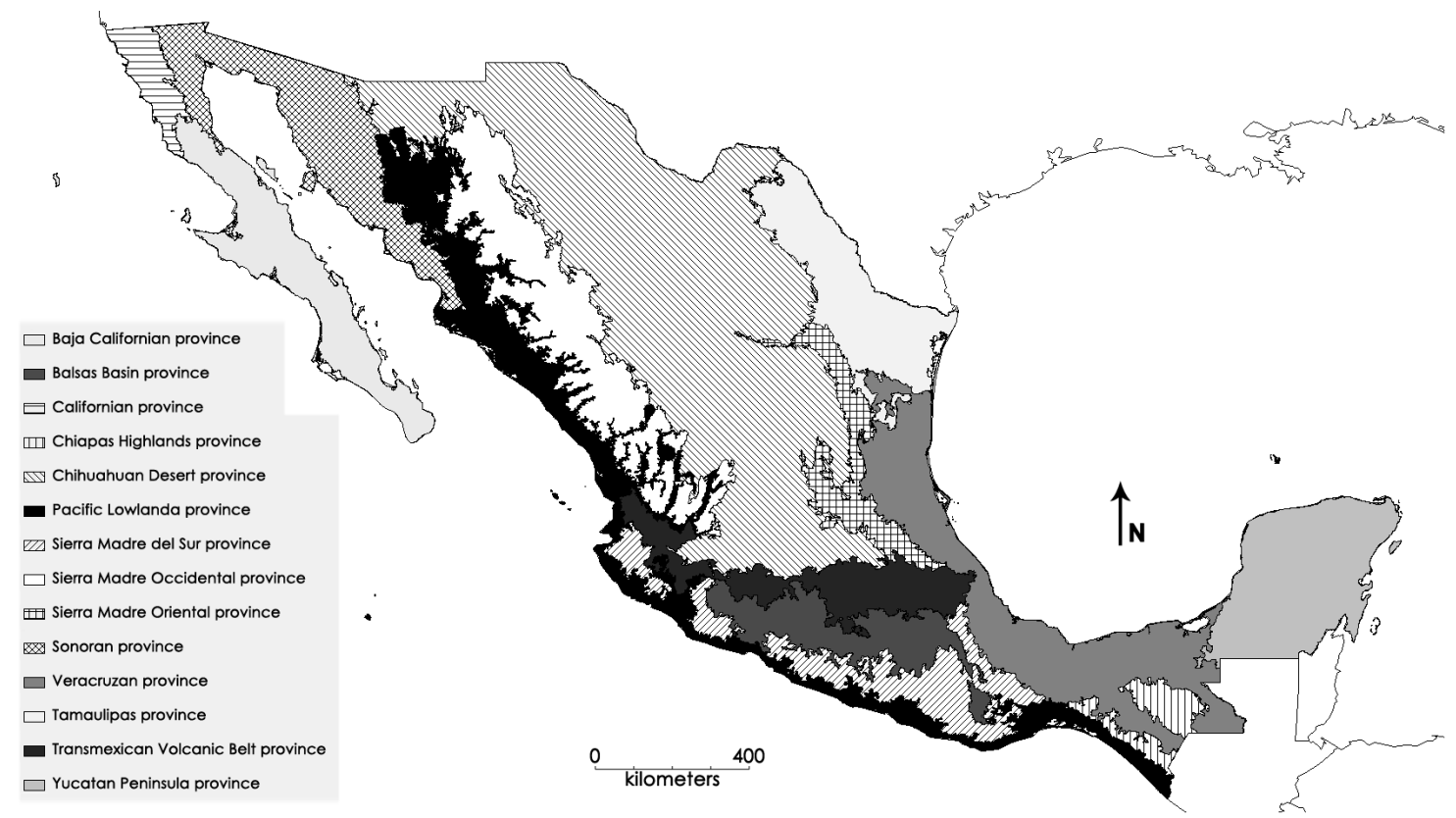

Figure 1. Biogeographic provinces of Mexico according to Morrone et al. (2017).

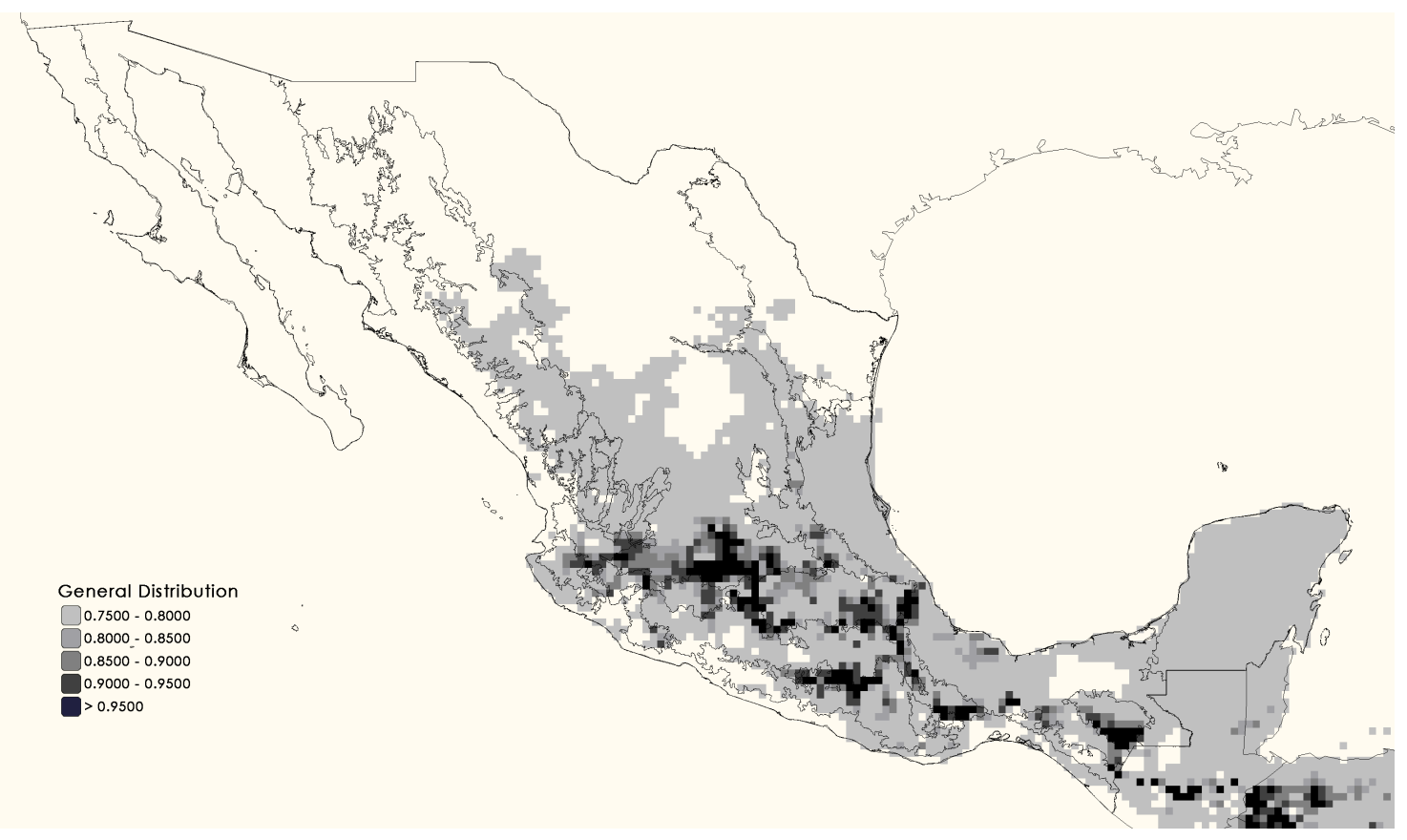

Figure 2. General distribution in natural way of cherimoya (Annona cherimola Mill.) in Mexico divided in the biogeographic provinces reported by Morrone et al. (2017).

showed precipitation of $209.4 \mathrm{~mm}$ (Figure 4F) and the driest of $21.8 \mathrm{~mm}$ (Figure $4 \mathrm{~F}$ ). These climatic traits according to Köppen classification modified by García (2004) corresponded with a $C(m)(w)$ climate (wet temperate with summer rainfall).

The cluster 2 had an average elevation of 1241.2 masl. Moreover, it showed the highest mean temperature, although with similar values to cluster 3 (Figure
$4 \mathrm{D})$ with a mean temperature of $21{ }^{\circ} \mathrm{C}$ (Figure 4B), a temperature differential between 11.5 and $16.2{ }^{\circ} \mathrm{C}$ (Figure 4E). This cluster showed the minimal temperature of the coldest month was $10.4{ }^{\circ} \mathrm{C}$ (Figure 4B) and maximal temperature of the warmest month was $30.7{ }^{\circ} \mathrm{C}$ (Figure 4B). It also showed an average annual rainfall of $1079.3 \mathrm{~mm}$ (Figure 4B) where the wettest month showed precipitation of $208.7 \mathrm{~mm}$ (Figure $4 \mathrm{~F}$ ) 


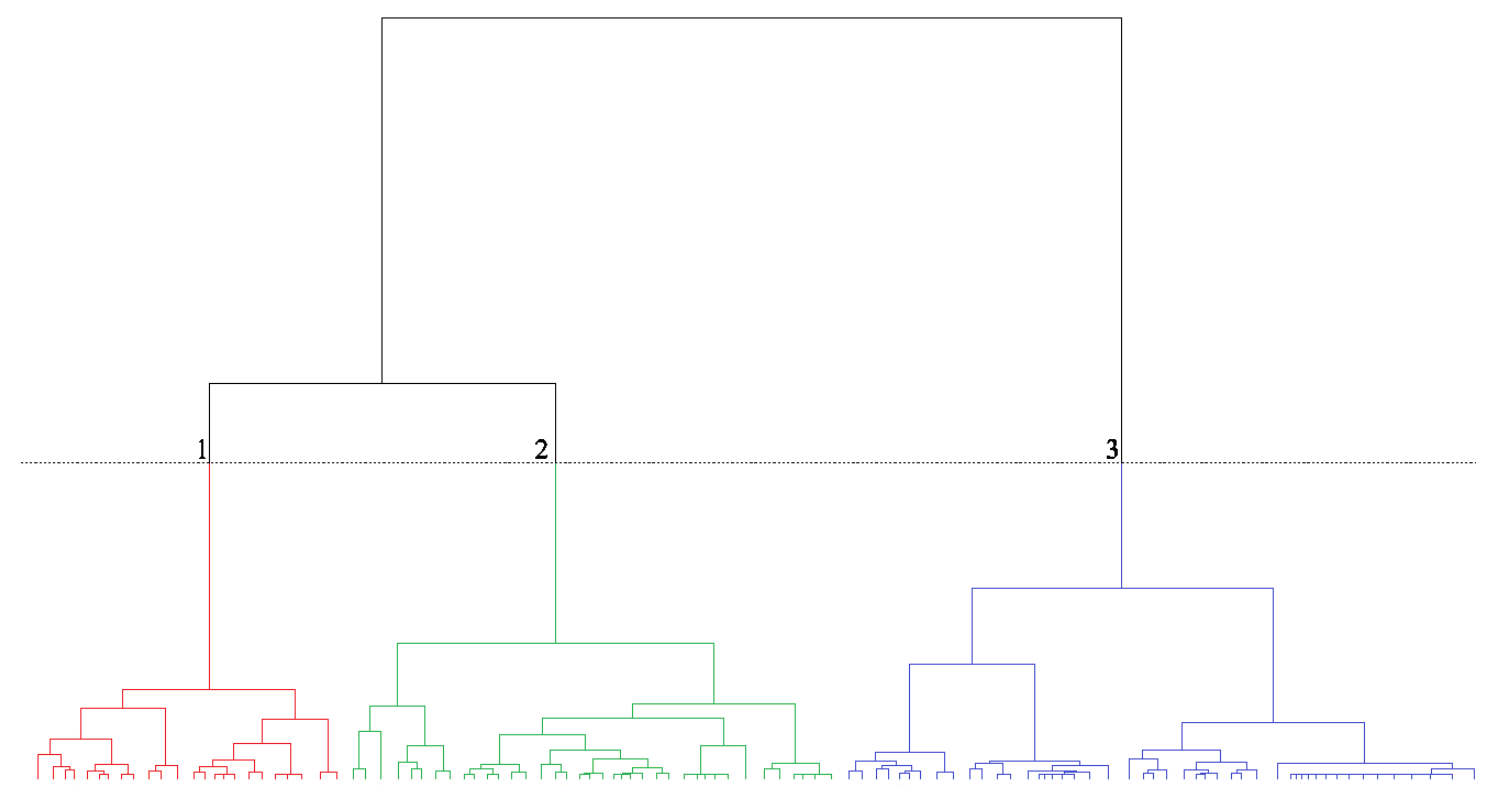

Figure 3. Dendrogram of the accessions of cherimoya (Annona cherimola Mill.) by means the climatic traits of its distribution using the method of Ward.

and the driest of $8.8 \mathrm{~mm}$ (Figure $4 \mathrm{~F}$ ) and showed $3.42 \%$ of winter rainfall. These climatic traits are according to Köppen classification modified by García (2004) corresponded with an $(A) C\left(e^{\prime}\right)$ climate (very extreme semi-warm of the temperate group with summer rainfall).

The cluster 3 had an average elevation of 1146.4 masl. Furthermore, it showed similar mean temperature values to cluster 2 (Figure 4D) with a mean temperature of $19.7{ }^{\circ} \mathrm{C}$ (Figure $4 \mathrm{C}$ ), a temperature differential between 8.7 and $10.9{ }^{\circ} \mathrm{C}$ (Figure $4 \mathrm{E}$ ). This cluster showed the minimal temperature of the coldest month was $12.2{ }^{\circ} \mathrm{C}$ (Figure $4 \mathrm{C}$ ) and maximal temperature of the warmest month was $26.7^{\circ} \mathrm{C}$ (Figure $4 \mathrm{C}$ ). It also showed an average annual rainfall of $1703.8 \mathrm{~mm}$ (Figure 4C) where the wettest month showed precipitation of $294.7 \mathrm{~mm}$ (Figure $4 \mathrm{~F}$ ) and the driest of 39.2 $\mathrm{mm}$ (Figure $4 \mathrm{~F}$ ) and showed $7.42 \%$ of winter rainfall. These climatic traits according to Köppen classification modified by García (2004) corresponded with an (A) $C(e)$ climate (extreme semi-warm of the temperate group with summer rainfall). 

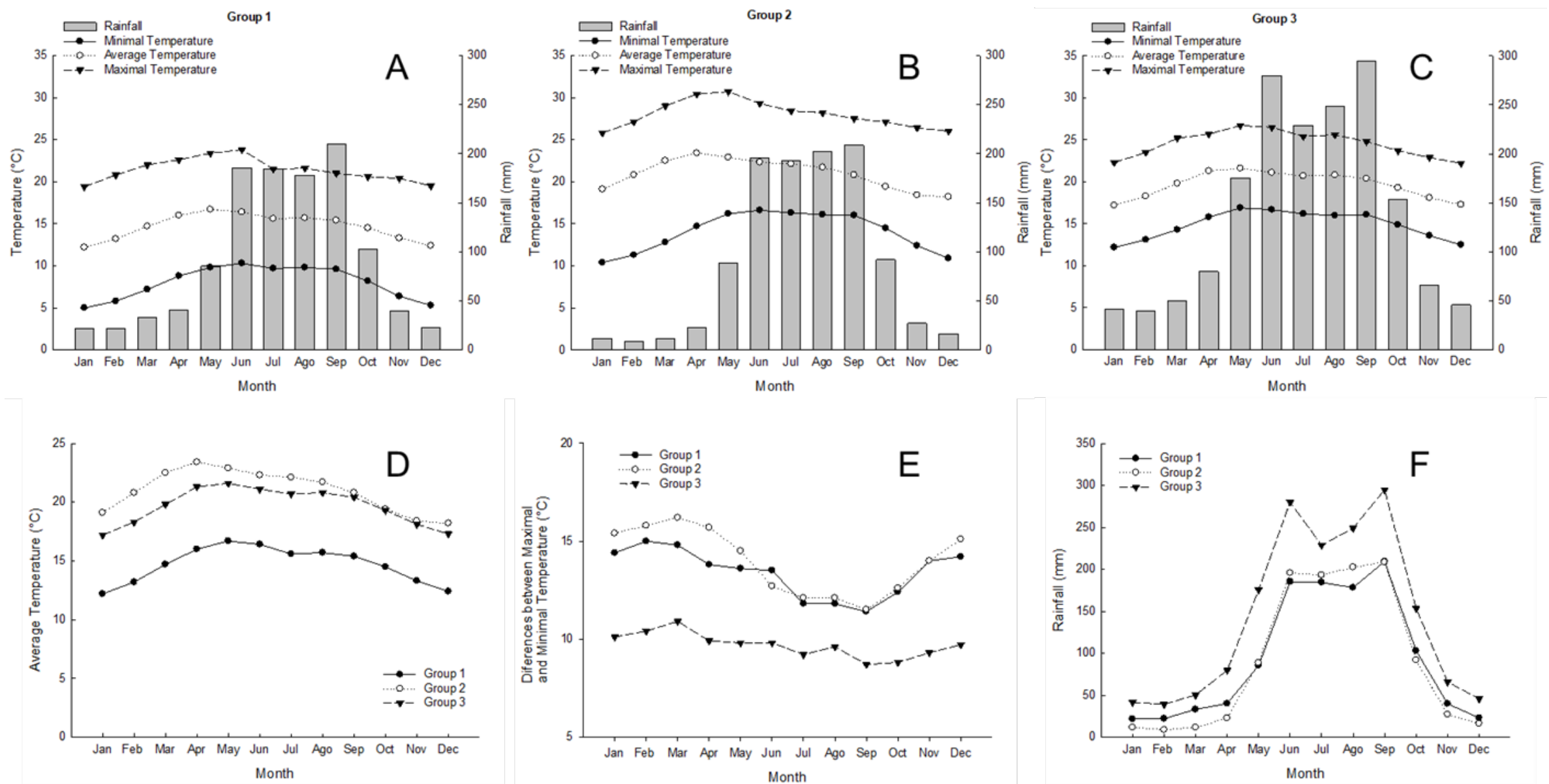

Figure 4. Climograms of the three eco-climatic groups of cherimoyas (Annona cherimola Mill.) (4A, 4B, and 4C, respectively) and the comparison of these groups into mean temperature $(4 \mathrm{D})$, temperature differential $(4 \mathrm{E})$, and rain $(4 \mathrm{~F})$. 
The distribution of cluster 1 was mainly located in the eastern Trans-Mexican Volcanic Belt, northern Sierra Madre del Sur, and north region of the Chiapas Highlands (Figure 5). These regions correspond to the south of the state of Queretaro in the border to Guanajuato, the northern State of Mexico, southern Hidalgo, Tlaxcala, west central Puebla, northeaster Oaxaca, and North of Chiapas Highlands.

Meanwhile, the distribution of cluster 2 was mainly located in centre, south, and west of Sierra Madre del Sur, western Trans-Mexican Volcanic Belt, south region of Chiapas Highlands with important zones in the extreme regions in the south of the Pacific Lowlands (Figure 6). These regions correspond to the west and south-eastern Jalisco, southern Guanajuato, north and eastern Michoacán, west and centre of Oaxaca, and centre of Chiapas.

Finally, the distribution of cluster 3 was strictly located, almost exclusivity, for the region where converge the Trans-Mexican Volcanic Belt, Veracruzan, Sierra Madre Oriental, and Sierra Madre del Sur provinces, and also, although with lesser probability, in some parts of eastern Yucatan Peninsula (Figure 7). These regions correspond to central east of Puebla, central west of Veracruz and Quintana Roo.

When comparing the climatic factors of the three groups where cherimoya germplasm grows in Mexico constitutes an important reference to select specific genotypes for each climatic group because the benefits that represent their satisfactory adaptation and their competitivity mainly considering the presence of creole materials in each one of the eco-climatic regions where cherimoya is distributed (Zagaja 1988). For instance, guava (Psidium guajava L.) had two genetic pools, one tropical and other subtropical (CázaresSánchez et al. 2010), and it is shown that tropical accessions have a higher sensibility to frost (Mondragón-Jacobo et al. 2010). Rajan et al. (2007) indicated that to improve crops it is necessary to have a gene pool, which is protected in a natural way in the genetic diversity of each species. In this sense, the cultivars could not have a good adaptation to more than one eco-climatic region (Núñez-Colín and Goytia-Jiménez 2009; Cazares-Sánchez et al. 2010). Therefore, to select and to identify specific cherimoya accessions for each eco-climatic region of their distribution will allow to find desirable genes to incorporate into cultivars such as tolerance or resistance to plagues, diseases, and abiotic stresses as well as to improve fruit quality and productivity (Quamme and Stushnoff 1988; Sistrunk and Moore 1988; Callahan 2003).

The distribution of the eco-climatic groups presented here disagree to the results by Segura et al. (2012) — who used similar GIS analyses but there did not specify weights of the variables nor coefficient of rain transform - because it was found here more ecoclimatic groups and they were distributed in different regions those reported by these authors.

The soil type is not a determinant limiting for the growth of this plant, because chirimoya adapts to various types of soil, such as sandy, sandy clayey, clayey, or stony soil. What they need is a soil with good drainage, as they do not resist flooding soils. The most suitable soil pH is between 6.0 and 7.5 (Rosell García et al., 1997).

Something important in this crop is the frequent lack of potassium, with the appearance of foliar margins with discolorations that evolve to necrosis (Navia and Valenzuela, 1978). It has been observed that the demand for nitrogen increases with the plant's own development (George, 1984). Calcium and magnesium requirements are important, especially in the last phase of fruit growth, prior to maturation. It is proposed that $A$. cherimola depends on mycorrization for optimal growth, above all favourable results are highlighted with the use of Glomus deserticola. This mycotrophic character of $A$. cherimola has been described by several authors (Azcón-Aguilar et al., 1994a, 1994b), therefore the wide range of soil type in which the plant adapts.

According to Morín (1983) establishing a plantation of Annona should be borne in mind that agroclimatological conditions - which are suitable for the normal development of the crop- considers that the climate is the most important aspect than the soil type.

The soil distribution of Chirimoyo in Mexico is characterized by the different ranges mountains which presented in mayor percentage the soil type called Feozem, mainly along the Transmexican Volcanic Axis, the Sierra Madre Occidental, the Yucatan Peninsula, and Southern of Chihuahuan Desert; it can be presented in any type of relief and climate, except in rainy tropical regions or very desert areas. It is the fourth most abundant soil type in Mexico, and is characterized by having a dark, soft surface layer, rich in organic matter and nutrients and variable depth. The second type of soil where chirimoya is found is the regosol characterized by light colours and poor in organic matter. In Mexico, they constitute the second most important type of soil by their extension. They are often associated with litosoles and with rock outcrops or tepetate. They are often shallow, their fertility is variable, and their productivity is conditioned on depth and stoniness. And thirdly, the soils in which chirimoya develops are vertisol soils, which present as their main characteristic a little differentiation of their horizons, due to internal movements of materials and the formation of large cracks in the summer periods, which have their origin in a high content in expansive clays. They develop in 


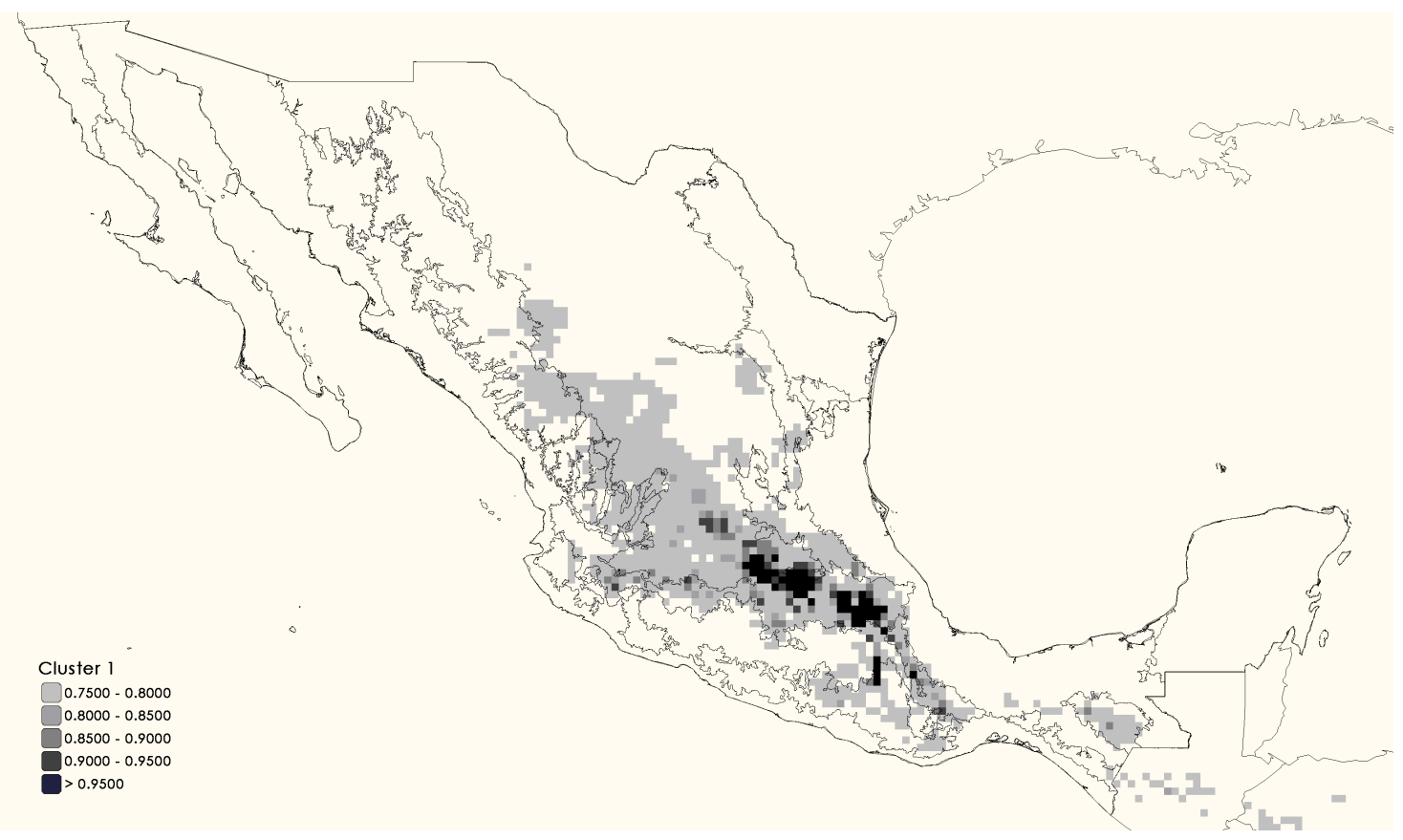

Figure 5. Distribution of the group 1 (climate $C(m)(w)$ ) of cherimoya (Annona cherimola Mill.) in Mexico divided in its biogeographic provinces reported by Morrone et al. (2017).

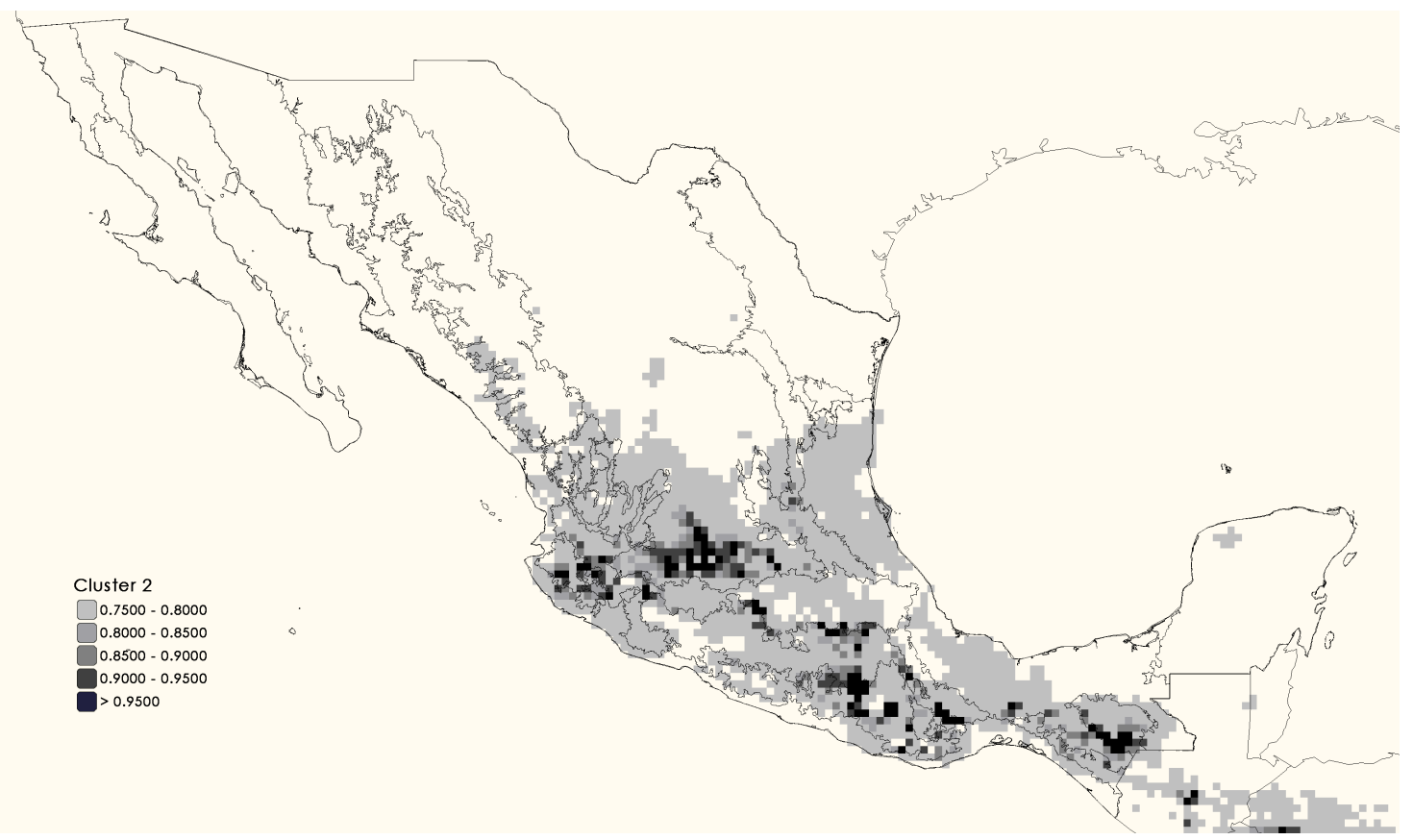

Figure 6. Distribution of group 2 (climate $(A) C\left(e^{\prime}\right)$ ) of cherimoya (Annona cherimola Mill.) in Mexico divided in its biogeographic provinces reported by Morrone et al. (2017).

flat or slightly inclined reliefs and on loamy materials or tertiary loamy limestone (Rzedowski, 1993; Andrés Agustín, 2015, INEGI, 2008).

To prove the inference about the existence of different genetic pools, according to the reported ecoclimatic clusters, it is necessary morphological and molecular characterization studies to be certain of these different genetic pools. Furthermore, the importance to collect germplasm of the three eco-climatic clusters for preservation and to the management of cherimoya genetic resources should be a priority to corroborate the possible Mesoamerican origin of this 


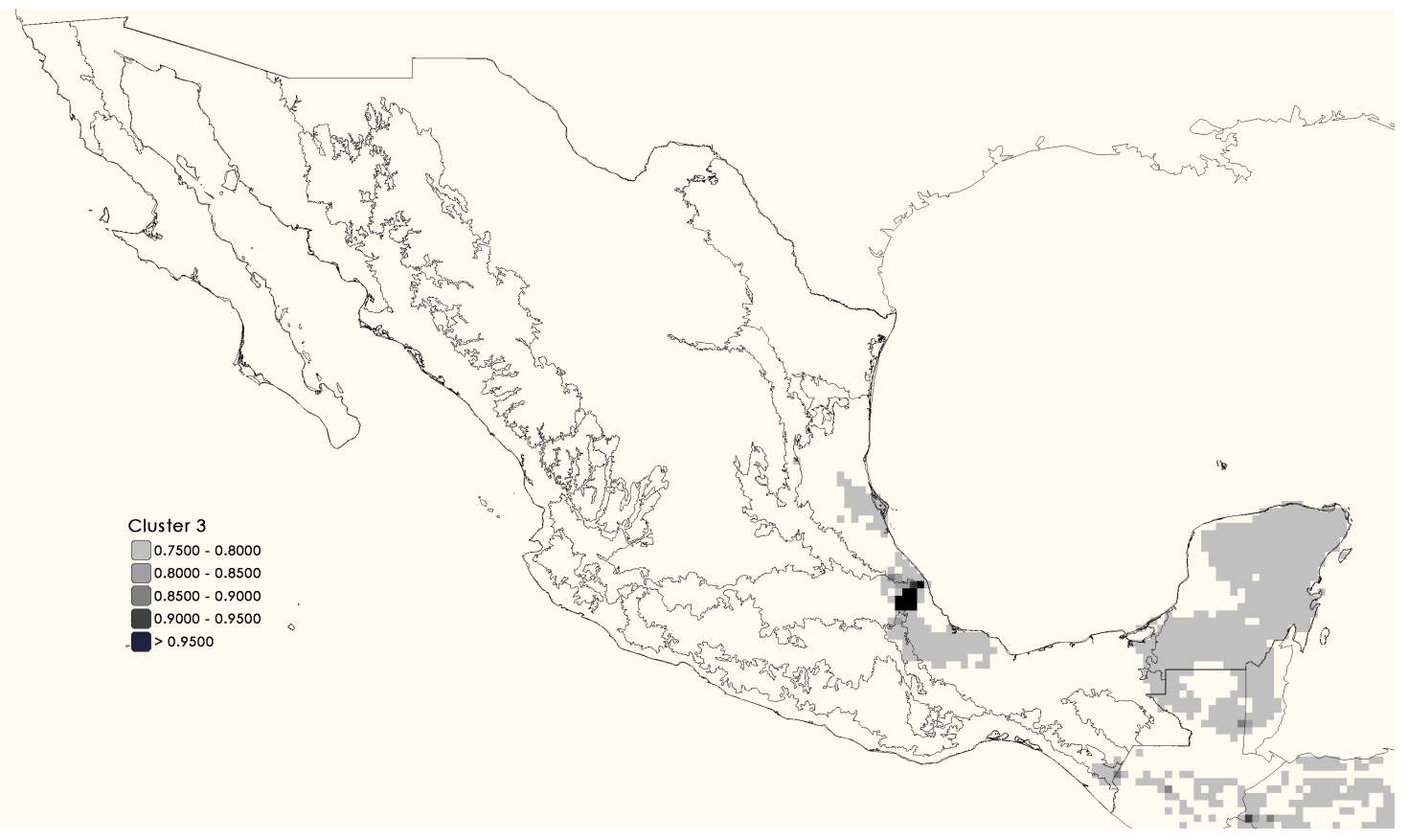

Figure 7. Distribution of group 3 (climate $(A) C(e)$ ) of cherimoya (Annona cherimola Mill.) in Mexico divided in its biogeographic provinces reported by Morrone et al. (2017).

species proposed by Larranaga et al. (2017). Besides, it would be advisable to develop an ethnobotanical study to know the role of the human being in the distribution of the cherimoya in the three eco-climatic regions found in this work.

\section{Modelling of potential growing regions of the cherimoya}

The modelling done by the Eco-crop algorithm showed the regions where the cherimoya can have excellent, very suitable, suitable, marginals, and very marginal the growing conditions in Mexico considering as main limiting factors the minimal temperature and rainfall during the growing season.

The CPGR model, using the Worldclim climatic database - real climatic data- (WC; Hijmans et al., 2005 ) in the Eco-crop algorithm, showed that the cherimoya had excellent adaptation regions in centre and west of the Trans-Mexican Volcanic Belt, western Sierra Madre Occidental, centre and south of Sierra Madre Oriental and all Sierra Madre del Sur and all Chiapas Highlands provinces including the region of the Pacific Lowlands province between the two parts of Chiapas Highlands (Figure 8). Also, very suitable regions were in the Yucatan Peninsula, Veracruzan, and the Pacific Lowlands provinces (Figure 8).

Meanwhile, the FPGR model, using CCM3 climatic database - simulating the effect of climatic change - (Govindasamy et al., 2003) in the Eco-crop algorithm, showed that the cherimoya retains most of the excellent adaptation regions of the CPGR model, but loss the region of the Pacific Lowlands province between the two parts of Chiapas Highlands and also loss very suitable regions in the Veracruzan, Pacific Lowlands and Yucatan Peninsula provinces (Figure 9).

Nevertheless, it was shown that the climate change does not significantly affect the regions with excellent growing conditions for cherimoya in Mexico.

With the modelling potential growing regions results, it is possible to promote an extension of the current growing regions of cherimoya, which now still are very smalls orchards or backyard orchards in Mexico, although it is important to make a study of the types of soil before planting in some regions because of Annonaceae species, one of the factors with the greatest impact on their adaptation and acclimatization is a good drainage soil (Andrés Agustín and Nieto Ángel 1997; Agustín 1999; Andrés-Agustín et al. 2004; Andrés Agustín 2002, 2015). The potential of cherimoya has been studied in South America (Morales Astudillo et al. 2004; Pinto et al. 2005; Vanhove and Van Damme 2013) and the Caribbean region (González Vega 2013) as well as the economic importance of this fruit in Spain, which was reported since '90s (Farré and Hermoso 1997), thus cherimoya could be an alternative fruit crop for some of these regions. These results also showed that Mexico can be a potential producer of cherimoya because have many potential growing regions to cultivate this fruit. 


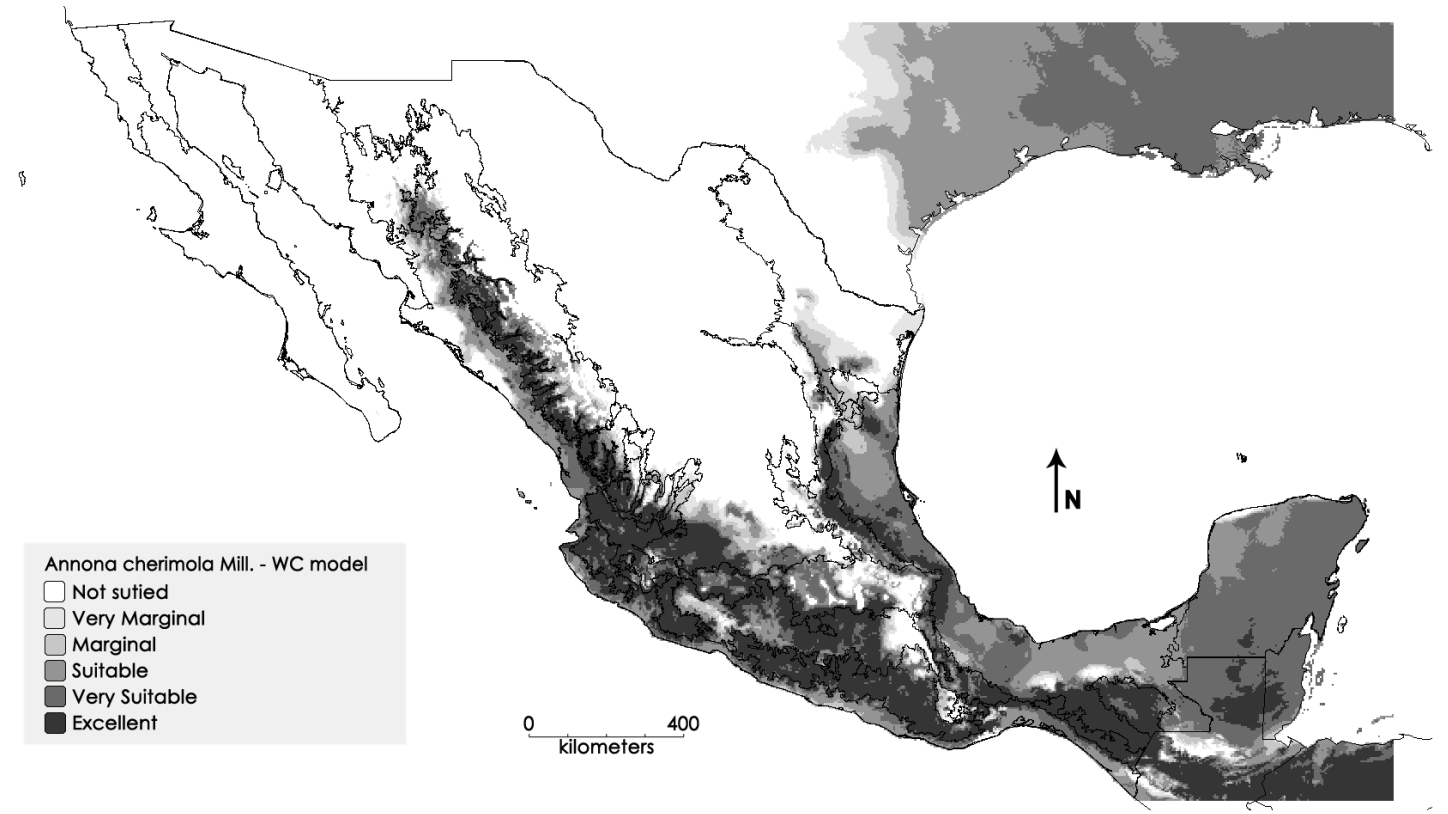

Figure 8. Eco-Crop model to know the potential growing areas of cherimoya (Annona cherimola Mill.) in Mexico using the Worldclim climatic database (Hijmans et al., 2005) presented in a map divided in the biogeographic provinces reported by Morrone et al. (2017).

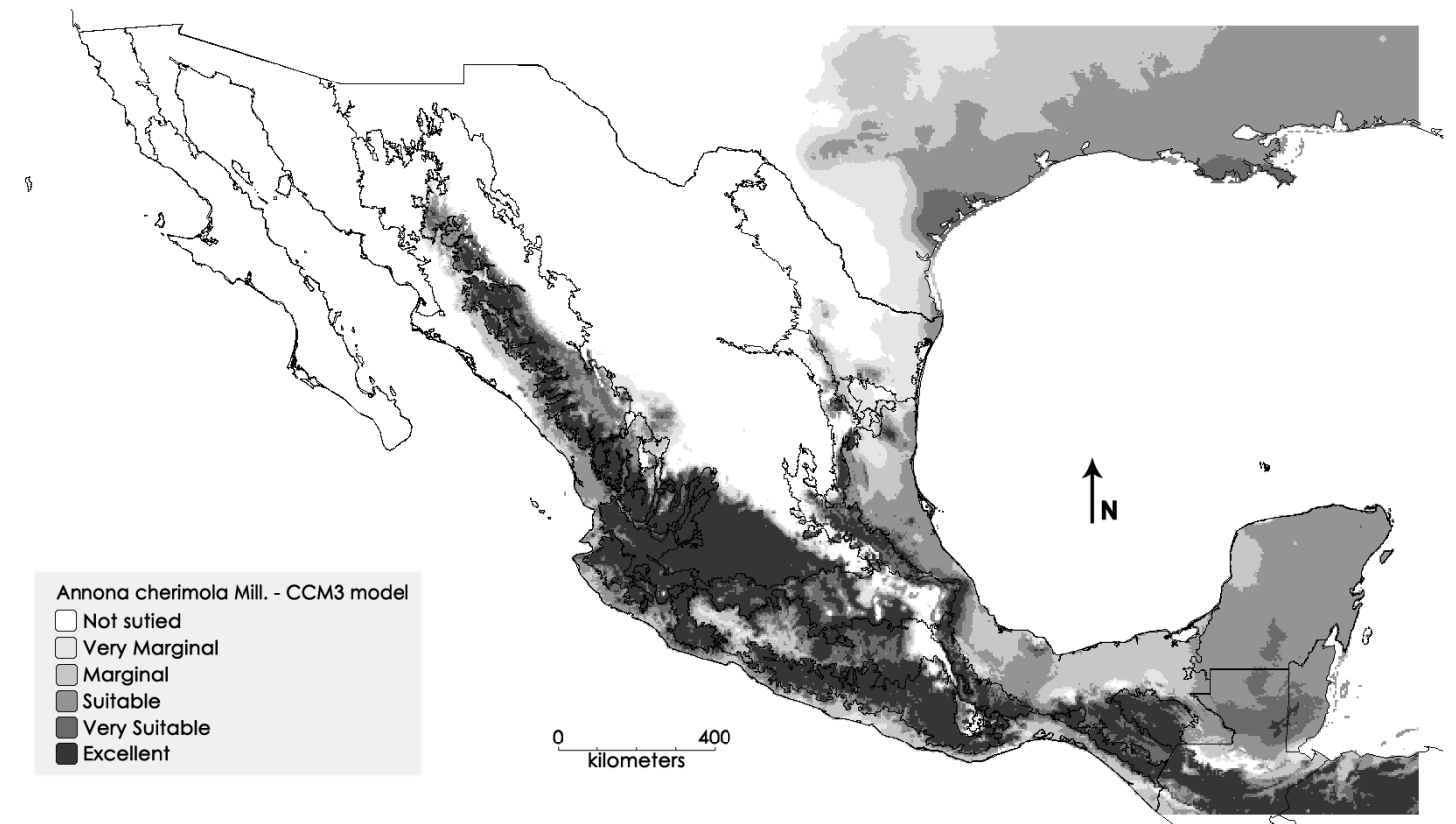

Figure 9. Eco-Crop model to know the potential growing areas of cherimoya (Annona cherimola Mill.) in Mexico using the model climatic database CCM3 (Govindasamy et al., 2003) presented in a map divided in the biogeographic provinces reported by Morrone et al. (2017).

\section{CONCLUSION}

In conclusion, there were located three ecoclimatic clusters of the cherimoya distribution in Mexico that correspond to climates $C(m)(w),(A) C\left(e^{\prime}\right)$ and $(A) C(e)$, respectively. Where cluster 3 showed the most restricted distribution.
The potential excellent growing regions of cherimoya were located in the Trans-Mexican Volcanic Belt, Sierra Madre Occidental, Sierra Madre Oriental, Sierra Madre del Sur, and Chiapas Highlands provinces.

When comparing the models with Worldclim data 
with CCM3 model data, there were not significant different. That is why, the climatic change does not significantly affect the excellent growing regions of Cherimoya in Mexico.

\section{ACKNOWLEDGEMENT}

To Comisión Nacional de Biodiversidad, Mexico (CONABIO) for facilitating the obtaining of passport data of the Red Mesoamericana de Biodiversidad (REMIB) for this research.

This research was supported by SAGARPACONACYT fund through the project 266891 and by Universidad de Guanajuato with the concurrent grant by the project CIIC 006/2019.

\section{DATA AVAILABILITY}

The data used to support the findings of this study are available from the corresponding author upon reasonable request.

\section{CONFLICT OF INTEREST}

The authors have no conflicts of interest to declare.

\section{CONTRIBUTION STATEMENT}

Conceived of the presented idea: CANC, ECR

Curated and validated of the data: IAT, SAOA, JAA, CANC

Carried out the data analysis: CANC, VPC

Wrote the first draft of the manuscript: JRRN, TJMS, CANC

Review and final write of the manuscript: CANC, TJMS, JRRN, ECR

Supervision: CANC

\section{REFERENCES}

Agustín JA (1999) Advances in research on genetic resources of cherimoya (Annona cherimola mill.) in Michoacan state, Mexico. Acta Horticulturae 497:189-200.

Andrés Agustín J (2002) La Chirimoya (Annona cherimola Mill): un frutal con alto potencial de cultivo en las regiones subtropicales de México. In: Cruz Castillo JG, Torres Lima PA (Comp.). Frutales para México: contribuciones del Caribe y Sudamérica. Universidad Autónoma Metropolitana-Universidad Autónoma Chapingo-Fundación Salvador Sánchez Colín, Chapingo, pp. 85-99.
Andrés Agustín J (2015) Situación actual de las investigaciones de las Anonáceas en México. In: Vidal Lezama E, Vidal Martínez NA, Vidal Hernández L (Comp.). Anonáceas. Plantas antiguas. Estudios Recientes. Parte 2. Universidad Autónoma Chapingo, Chapingo, pp. 27-40.

Andrés Agustín J, Nieto Ángel D (1997) El cultivo de la chirimoya (Annona cherimola Mill.) en México. In: São José AR, Souza IVB, Morais OM, Rebouças TNH (eds.). Anonáceas. Produção e Mercado (Pinha, Graviola, Atemóia e Cherimólia). Universidade Estadual do Sudoeste da Bahia, Vitoria da Conquista, pp. 7-19.

Andrés-Agustín J, Segura-Ledesma S (2014) Conservación y uso de los recursos genéticos de Annonaceae en México. Revista Brasileira de Fruticultura 36: 118-124. doi: 10.1590/S010029452014000500014

Azcón-Aguilar C, Encina CL, Azcón R, Barea JM (1994) Mycotrophy of Annona cherimola and the morphology of its mycorhizae. Micorrhyza 4: pp. 161-168.

Azcón-Aguilar C, Encina CL, Azcón R, Barea JM (1994) Effect of arbuscular Micorrizha on the growth and development of micropropagated Annona cherimola plants. Agricultural Science in Finland 3: 281-288.

Bonavia D, Ochoa CM, Tovar SO, Cerrón Palomino R (2004) Archaeological evidence of cherimoya (Annona cherimola Mill.) and guanabana (Annona muricata L.) in ancient Peru. Economic Botany 58:509-522.

Callahan AM (2003) Breeding for Fruit Quality. Acta Horticulturae 622:295-302.

Cazares-Sanchez E, Núñez-Colín CA, DomínguezÁlvarez JL, Luna-Morales CC, Rojas-Martínez RI, Segura-Ledesma S (2010) Potential biogeographic distribution of guava (Psidium guajava L.) in Mexico. Acta Horticulturae 849:55-62.

Chatrou LW, Erkens RHJ, Richardson JE, Saunders RMK, Fay MF (2012) The natural history of Annonaceae. Botanical Journal of the Linnean Society 169:1-4.

Dobzhansky T (1970) Genetics of the evolutionary process. Columbia University Press, New York, USA.

Domínguez J, Castañeda A (2002) Guía técnica para la producción de chirimoya. Fundación Salvador Sánchez Colín, Coatepec de las Harinas, Mexico.

Farré JM, Hermoso JH (1997) El chirimoyo ( $\boldsymbol{A} \boldsymbol{n}$ - 
nona cherimola Mill.) en España. São José AR, Souza IVB, Morais OM, Rebouças TNH (eds.). Anonáceas. Produção e Mercado (Pinha, Graviola, Atemóia e Cherimólia). Universidade Estadual do Sudoeste da Bahia, Vitoria da Conquista, pp. 84-87.

Food and Agriculture Organization of the United Nations (FAO) (2007) Eco-crop database [FAO] Accessed 1 March 2017

García, E. (2004) Modificaciones al sistema de clasificación climática de Köppen. 5 ed. Universidad Nacional Autónoma de México, Mexico city, Mexico.

George AP (1984) Annonaceae. In: Page PE (ed.) Tropical tree fruits for Australia. Queensland Department of Primary Industries, Queensland, pp. 35-41.

González Vega ME (2013) Chirimoya (Annona cherimola Miller), frutal tropical y subtropical de valores promisorios. Cultivos Tropicales 34:52-63.

Govindasamy B, Duffy PB, Coquard J (2003) Highresolution simulations of global climate, part 2: effects of increased greenhouse cases. Climate Dynamics 21:391-404.

Guarino L, Jarvis A, Hijmans RJ, Maxted N (2002) Geographic Information Systems (GIS) and the conservation and use of plant genetic resources. In: Engels JMM, Ramanatha Rao V, Brown AHD, Jackson MT (eds.). Managing Plant Genetic Diversity. International Plant Genetic Resources Institute (IPGRI), Rome, pp. 387-404.

Hijmans RJ, Cameron SE, Parra JL, Jones PG, Jarvis A (2005) Very high resolution interpolated climate surfaces for global land areas. International Journal of Climatology 25:1965-1978.

Hijmans RJ, Guarino L, Cruz M, Rojas E (2001) Computer tools for spatial analysis of plant genetic resources data: 1. DIVA-GIS. Plant Genetic Resources Newsletters 127:15-19.

Hijmans RJ, Guarino L, Mathur P (2012) DIVAGIS: version 7.5. User Guide. Lizard Tech, Inc. and the University of California, Berkeley, USA.

Hijmans RJ, Graham CH (2006) The ability of climate envelope models to predict the effect of climate change on species distributions. Global Change Biology 12:2272-2281.

INEGI, Instituto Nacional de Estadística, Geografía e Informática (2008) Características edafológicas, fisiográficas, climáticas e hidrográficas de México. INEGI, Mexico city, Mexico.
Jones PG, Gladkov A (1999) FloraMap: a computer tool for predicting the distribution of plants and other organisms in the wild. Version 1.0. Centro Internacional de Agricultura Tropical, Cali.

Jones PG, Guarino L, Jarvis A (2002) Computer tools for spatial analysis of plant genetic resources data: 2. Floramap. Plant Genetic Resources Newsletters 130:1-6.

Larranaga N, Albertazzi FJ, Fontecha G, M. Palmieri, Rainer H, van Zonneveld M, Hormaza JI (2017) A Mesoamerican origin of cherimoya (Annona cherimola Mill.): Implications for the conservation of plant genetic resources. Molecular Ecology 26:4116-4130.

Missouri Botanical Garden (2017) Tropicos database http://www.tropicos.org Accessed 22 March 2017

Mondragón-Jacobo C, Toriz-Ahumada LM, GuzmánMaldonado SH (2010) Generation of PinkFleshed Guavas to Diversify Commercial Production in Central Mexico. Acta Horticulturae 849:333-340.

Morales Astudillo AR, Cueva B, Aquino Valarezo PS (2004) Genetic diversity and geographic distribution of Annona cherimola in Southern Ecuador. Lyonia 7:159-170.

Morrone JJ, Escalante T, Rodríguez-Tapia G (2017) Mexican biogeographic provinces: Map and shapefiles. Zootaxa 4277:277-279.

Navia VM, Valenzuela J (1978) Sintomatología de deficiencias nutricionales en chirimoya ( $A n$ nona cherimola Mill.) cv. Bronceada. Agricultura Técnica (Chile) 38: 9-14.

Núñez-Colín CA, Alia-Tejacal I, Villarreal-Fuentes JM, Escobedo-López D, Rodríguez-Núñez JR, PeñaCaballero V (2017) Distribution, eco-climatic characterization and potential cultivation zones of mamey sapote in Mexico. Revista Chapingo Serie Horticultura 23:83-96.

Núñez-Colín CA, Goytia-Jiménez MA (2009) Distribution and agroclimatic characterization of potential cultivation regions of physic nut in Mexico. Pesquisa Agropecuaria Brasileira 44:10781085 .

Pinto ACQ, Cordeiro MCR, de Andrade SRM, Ferreira FR, Filgueiras HAC, Alves RE, Kinpara DI (2005) Annona species. International Centre for Underutilised Crops-University of Southampton, Southampton, UK.

Pozorsky T, Pozorsky S (1997) Cherimoya and 
guanabana in the archaeological record of Peru. Journal of Ethnobiology 17:235-248.

Quamme HA, Stushnoff C (1988) Resistencia al estrés ocasionado por el medio ambiente. In: Moore JN, Janick J (eds.) Métodos genotécnicos en frutales. AGT Editor, Mexico city, pp. 323-355.

Rajan S, Yadava LP, Kumar RAM, Saxena SK (2007) GIS based diversity analysis of guava growing distribution in Uttar Pradesh. Acta Horticulturae 735:109-113.

Rzedowski J (1993) Diversity and origins of the phanerogamic flora of Mexico. In: Ramamoorthy TP, Bye R, Lot A, Fa J (eds.) Biological Diversity of Mexico. Origins and Distribution. Oxford University Press, New York, pp. 129-144.

Rosell García P, Galán Saúco V, Hernández Delgado PM (1997) Cultivo del chirimoyo en Canarias. Consejería de Agricultura, Pesca y Alimentación, Gobierno de Canarias, Santa Cruz de Tenerife, Spain.

Scheldeman X, van Zonneveld M (2011) Manual de Capacitación en Análisis Espacial de Diversidad y Distribución de Plantas. Bioversity International, Rome, Italy.

Segura S, Andrés J, Fresnedo J, Zavala F, Marroquín L, Vidal E, Nicolás M, Vidal L, Bolívar N, Castañeda A, González A, Barrios S, Carmona A (2012) Where Do We Go with Annona in Mexico? Acta Horticulturae 948:79-90.

SIAP, Servicio de Información Agroalimentaria y Pesquera (2020) Cierre de la producción agrícola 2019 (México). [https://nube.siap.gob.mx/cierreagricola] Accessed
10 August 2020.

Sistrunk WA, Moore JN (1988) Calidad. In: Moore JN, Janick J (eds.) Métodos genotécnicos en frutales. AGT Editor, Mexico city, pp. 367-395.

Vanhove W, Van Damme P (2013) Value chains of cherimoya (Annona cherimola Mill.) in a centre of diversity and its on-farm conservation implications. Tropical Conservation Science 6:158180 .

van Zonneveld M, Scheldeman X, Escribano P, Viruel MA, Van Damme P, García W, Tapia C, Romero J, Sigueñas M, Hormaza JI (2012) Mapping Genetic Diversity of Cherimoya (Annona cherimola Mill.): Application of Spatial Analysis for Conservation and Use of Plant Genetic Resources. Plos One 7:e29845.

Villaseñor JL (2003) Diversidad y distribución de las Magnoliophyta de México. Interciencia 28:160-168

Wright S (1978) Evolution and the genetics of populations. Vol. 4 Variability within and among natural populations. University of Chicago Press, Chicago, USA.

Zagaja SW (1988) Exploración de recursos genéticos. In: Moore JN, Janick J (eds.) Métodos genotécnicos en frutales. AGT Editor, Mexico city, pp. 3-12.

Received: 28 July 2020

Accepted: 20 September 2020

Available: 10 October 2020 


\section{Additional Files}

Add File 1. Project and source of the passport data of Annona cherimola Mill. used in the GIS analysis from the SNIB-CONABIO database of the Comisión Nacional de Biodiversidad (CONABIO), Mexico.

\begin{tabular}{|c|c|c|c|}
\hline Project & Source & Cite of the project & $\begin{array}{c}\text { Number of } \\
\text { used data }\end{array}$ \\
\hline 115 & $\begin{array}{l}\text { REMIB-AZ } \\
\text { herbarium }\end{array}$ & $\begin{array}{l}\text { Mc Laughlin, P. S. 2003. Herbario de la Universidad de Arizona, EUA (ARIZ). Universidad de } \\
\text { Arizona. EUA. Bases de datos SNIB-CONABIO. México, D.F. }\end{array}$ & 2 \\
\hline 138 & $\begin{array}{l}\text { REMIB- } \\
\text { HINTON }\end{array}$ & $\begin{array}{l}\text { Hinton, G. 2012. Colección particular Hinton. Herbarium of Geo. B. Hinton. Bases de datos } \\
\text { SNIB-CONABIO. México, D.F. }\end{array}$ & 4 \\
\hline AA002 & $\begin{array}{ll}\text { AA002 } & \text { E008 } \\
\text { K004 } & \text { P026 } \\
\text { U021 }\end{array}$ & $\begin{array}{l}\text { Lorea-Hernández, F., Peredo, M. y C. Durán. 2014. Actualización de las bases de datos del } \\
\text { Herbario XAL. Fase III. Instituto de Ecología, A. C. }\end{array}$ & 76 \\
\hline AA007 & AA007 L282 & $\begin{array}{l}\text { Contreras Jiménez, J. L. 2005. Actualización e incremento de la base de datos del Herbario de } \\
\text { la Benemérita Universidad Autónoma de Puebla. Benemérita Universidad Autónoma de Puebla } \\
\text { DIHMO. }\end{array}$ & 10 \\
\hline $\mathrm{AC} 002$ & AC002 & $\begin{array}{l}\text { Zamora Crescencio, P., Sánchez-González, Ma. C. y L. Aragón-Axomulco. 2005. Formación del } \\
\text { banco de datos del herbario (UCAM). Universidad Autónoma de Campeche. Centro de Investiga- } \\
\text { ciones Históricas y Sociales. }\end{array}$ & 1 \\
\hline AS014 & AS014 & $\begin{array}{l}\text { Chávez León, G. 2006. Inventario florístico y faunístico del Parque Nacional Barranca del } \\
\text { Cupatitzio, Michoacán. Secretaría de Agricultura, Ganadería, Desarrollo Rural, Pesca y Ali- } \\
\text { mentación. Instituto Nacional de Investigaciones }\end{array}$ & 1 \\
\hline $\mathrm{B} 123$ & B123 & $\begin{array}{l}\text { Diego Pérez, N. 1997. Lista florística de la Costa Grande del estado de Guerrero. Universidad } \\
\text { Nacional Autónoma de México. Facultad de Ciencias. Bases de datos SNIB-CONABIO proyecto } \\
\text { No. B123. México, D.F. }\end{array}$ & 1 \\
\hline B133 & B133 & $\begin{array}{l}\text { Luna Vega, M. I. 1997. Florística y biogeografía de algunos bosques mesófilos de la Huasteca } \\
\text { Hidalguense: Fase I (Tenango de Doria y Tlanchinol). Universidad Nacional Autónoma de México. } \\
\text { Facultad de Ciencias. Bases de datos SNIB-CONABIO. Proyecto No. B133. México, D.F. }\end{array}$ & 3 \\
\hline $\mathrm{BC} 002$ & T031 & $\begin{array}{l}\text { Cuevas Sánchez, J. A. 2006. Computarización de la base de datos del Banco Nacional de Germo- } \\
\text { plasma Vegetal - Fase 2. Universidad Autónoma Chapingo. }\end{array}$ & 10 \\
\hline BC003 & BC003 & $\begin{array}{l}\text { Chávez Rendón, C. 2006. Actualización e incremento del banco de datos de la colección de herbario } \\
\text { del Jardín Etnobotánico de Oaxaca. Centro Cultural Santo Domingo. Bases de datos SNIB- } \\
\text { CONABIO proyecto No. BC003. México, D.F. }\end{array}$ & 3 \\
\hline $\mathrm{BC} 007$ & $\mathrm{BC} 007$ & $\begin{array}{l}\text { Fernández Nava, R., Reyes Toledo, B. y M. Casales Gómez. 2007. Computarización del Herbario } \\
\text { ENCB, IPN. Fase IV. Base de datos de la familia Pinaceae y de distintas familias de la clase } \\
\text { Magnoliopsida depositadas en el Herbario de la Escuela Nacional de Ciencias Biológicas-IPN }\end{array}$ & 29 \\
\hline
\end{tabular}


BE005 BE005 Reyes-García, A., Sousa Sánchez, M. y M. E. León Velasco. 2006. Inventario Florístico de la Reserva de la Biósfera La Sepultura del Corredor Biológico Sierra Madre del Sur. Fase II. Universidad Nacional Autónoma de México. Instituto de Biología. Bases de datos SNIB-CONABIO proyectos No. BE005 y Y003. México, D.F.

\begin{tabular}{|c|c|c|c|}
\hline BK004 & BK004 & $\begin{array}{l}\text { Salas Morales S. H. y A. Nava Zafra. 2007. Composición florística del Parque Nacional Huatulco. } \\
\text { Sociedad para el Estudio de los Recursos Bióticos de Oaxaca, A. C. (SERBO). Bases de datos } \\
\text { SNIB-CONABIO proyecto No. BK004. México, D.F. }\end{array}$ & 1 \\
\hline BK029 & BK029 & $\begin{array}{l}\text { Téllez Valdés, O. 2011. Base de datos de la distribución de la flora de la Reserva de la Biosfera } \\
\text { Tehuacán-Cuicatlán. Universidad Nacional Autónoma de México, Facultad de Estudios Superiores } \\
\text { Iztacala. Bases de datos SNIB-CONABIO, proyecto No. BK029. México D. F. }\end{array}$ & 1 \\
\hline CC010 & V050 CC010 & $\begin{array}{l}\text { Escobar Ocampo C. y J.J. Castillo Hernández. 2007. Sistematización de la colección entomológica } \\
\text { y actualización de la colección del herbario CHIP del Instituto de Historia Natural y Ecología } \\
\text { (IHNE), Chiapas. Secretaría de Medio Ambiente, Vivienda e Historia Natural. Bases de datos } \\
\text { SNIB-CONABIO Plantas, proyectos No. CC010, V050_plantas y H297. México, D.F. }\end{array}$ & 7 \\
\hline DC013 & DC013 & $\begin{array}{l}\text { Vázquez-Torres, M. y L. H. Bojórquez G. 2011. Base de datos computarizada del herbario CIB, } \\
\text { Instituto de Investigaciones Biológicas, Universidad Veracruzana. Universidad Veracruzana. Insti- } \\
\text { tuto de Investigaciones Biológicas. }\end{array}$ & 4 \\
\hline F019 & F019 & $\begin{array}{l}\text { González Espinosa, M. 1998. Árboles de Chiapas: registro georreferenciado de los ejemplares } \\
\text { depositados en el herbario de la Academia de Ciencias de California (CAS). El Colegio de la } \\
\text { Frontera Sur. Bases de datos SNIB-CONABIO proyecto No. F019. México, D.F. }\end{array}$ & 11 \\
\hline gbif & 11520 & $\begin{array}{l}\text { Netherlands Centre for Biodiversity Naturalis, section } \\
\text { Netherlands, National Herbarium of the } \\
\text { http://data.gbif.org/datasets/resource/11520, 2012-12-04 }\end{array}$ & 2 \\
\hline gbif & 12084 & $\begin{array}{l}\text { Missouri Botanical Garden, Missouri Botanical Garden (accessed through GBIF data portal, } \\
\text { http://data.gbif.org/datasets/resource/12084, 2012-12-04 }\end{array}$ & 12 \\
\hline gbif & 14128 & $\begin{array}{l}\text { California Academy of Sciences, CAS Botany (BOT) (accessed through GBIF data portal, } \\
\text { http://data.gbif.org/datasets/resource/14128, 2012-12-04 }\end{array}$ & 2 \\
\hline gbif & 1429 & $\begin{array}{l}\text { US National Plant Germplasm System, United States National Plant Germplasm System Collection } \\
\text { (accessed through GBIF data portal, http://data.gbif.org/datasets/resource/1429, 2012-12-04 }\end{array}$ & 1 \\
\hline gbif & 14346 & $\begin{array}{l}\text { Field Museum, Field Museum of Natural History (Botany) Seed Plant Collection (accessed through } \\
\text { GBIF data portal, http://data.gbif.org/datasets/resource/14346, 2012-12-04 }\end{array}$ & 9 \\
\hline gbif & 1496 & $\begin{array}{l}\text { University of Vienna, Institute for Botany - Herbarium WU, Herbarium WU (accessed through } \\
\text { GBIF data portal, http://data.gbif.org/datasets/resource/1496, 2012-12-04 }\end{array}$ & 1 \\
\hline gbif & 7900 & $\begin{array}{l}\text { University of Arizona Herbarium, UA Herbarium (accessed through GBIF data portal, } \\
\text { http://data.gbif.org/datasets/resource/7900, 2012-12-04 }\end{array}$ & 3 \\
\hline H076 & H076 & $\begin{array}{l}\text { Martínez, M. 1999. Flora acuática de Querétaro. Universidad Autónoma de Querétaro. Facultad } \\
\text { de Ciencias Naturales. Bases de datos SNIB-CONABIO proyecto No. H076. México, D.F. }\end{array}$ & 1 \\
\hline
\end{tabular}


Hidalguense: Fase II (Tlahuelompa y Eloxochitlán). Universidad Nacional Autónoma de México. Facultad de Ciencias. Bases de datos SNIB-CONABIO. Proyecto No. H102. México, D.F.

\begin{tabular}{|c|c|c|c|}
\hline H304 & H304 & $\begin{array}{l}\text { García Ruíz, I. 1999. Flora del Parque Nacional Pico de Tancítaro, Michoacán. Instituto } \\
\text { Politécnico Nacional. Centro Interdisciplinario de Investigación para el Desarrollo Integral } \\
\text { Regional-Michoacán. Bases de datos SNIB-CONABIO proyecto No. H304. México, D.F. }\end{array}$ & 1 \\
\hline HA005 & $\begin{array}{l}\text { EC009 } \\
\text { HA005 }\end{array}$ & $\begin{array}{l}\text { Pérez-Farrera, M. A., Martínez-Camilo, R., Martínez-Meléndez, N. y M. Martínez-Meléndez. } 2011 . \\
\text { Integración de bases de datos, actualización y sistematización de la colección de flora del Herbario } \\
\text { Eizi Matuda (HEM). Universidad de Ciencias y Artes de Chiapas }\end{array}$ & 6 \\
\hline HA008 & $\begin{array}{l}\text { ECO11 } \\
\text { HA008 }\end{array}$ & $\begin{array}{l}\text { Serrano, Valentina. 2012. Base de datos del Herbario de Querétaro 'Dr. Jerzy Rzedowski' } \\
\text { (QMEX). Fase II. Universidad Autónoma de Querétaro. Facultad de Ciencias Naturales. Bases } \\
\text { de datos SNIB-CONABIO, proyectos No. HA008 y EC011. México D. F. }\end{array}$ & 9 \\
\hline HA016 & BA006 & $\begin{array}{l}\text { Hernández Aguilar S. 2014. Depuración de la colección y base de datos del Herbario CICY. Fase } \\
\text { IV". CICY. Centro de Investigación Científica de Yucatán A.C. }\end{array}$ & 2 \\
\hline HE008 & BE018 & $\begin{array}{l}\text { Dávila, A. P., Rodríguez A.I. y R. L. García. 2012. Conservación "ex situ" de germoplasma vegetal } \\
\text { de las regiones áridas y semiáridas de México. Fase 4. FES Iztacala, UNAM. Banco de Semillas } \\
\text { FESI UNAM. Bases de datos SNIB-CONABIO, proyectos No. HE008, GE002, EE024 y BE018. } \\
\text { México D. F. }\end{array}$ & 1 \\
\hline INFyS2010 & INFyS. 2010 & $\begin{array}{l}\text { CONAFOR. 2011. Base de datos del Inventario Nacional Forestal y de Suelos } 2004 \text { - 2009, Comisión } \\
\text { Nacional Forestal y de Suelos, Zapopan, Jalisco, México }\end{array}$ & 16 \\
\hline J063 & J063 & $\begin{array}{l}\text { Reygadas Prado, D. D. 1999. Sistema de apoyo a la toma de decisiones para la reforestación } \\
\text { rural en México. Secretaría de Agricultura, Ganadería, Desarrollo Rural, Pesca y Alimentación. } \\
\text { Instituto Nacional de Investigaciones Forestales Agrícolas y Pecuarias }\end{array}$ & 4 \\
\hline J084 & J084 & $\begin{array}{l}\text { Batis Muñoz, A I., Alcocer Silva, M. I., Gual Díaz, M., Sánchez Dirzo, C. y C. Vázquez Yanes, } \\
\text { 1999. Árboles mexicanos potencialmente valiosos para la restauración ecológica y la reforestación. } \\
\text { Universidad Nacional Autónoma de México. Instituto de Ecología }\end{array}$ & 24 \\
\hline L057 & L057 & $\begin{array}{l}\text { Vega Aviña, R. 2000. Catálogo y base de datos preliminar de la flora de Sinaloa. Universidad } \\
\text { Autónoma de Sinaloa. Facultad de Agronomía. Bases de datos SNIB-CONABIO proyecto No. } \\
\text { L057. México, D.F. }\end{array}$ & 2 \\
\hline L091 & L091 & $\begin{array}{l}\text { Luna Vega, M. I. } 2000 \text {. Florística y biogeografía de algunos bosques mesófilos de la Huasteca } \\
\text { Hidalguense: Fase } 3 \text { (Chapulhuacán y Pisaflores). Universidad Nacional Autónoma de México. } \\
\text { Facultad de Ciencias. Bases de datos SNIB-CONABIO. Proyecto No. L091. México, D.F. }\end{array}$ & 1 \\
\hline M001 & M001 & $\begin{array}{l}\text { Berlin, B. 1999. La etnobiología de los recursos nutritivos en las comunidades Tzeltales en los } \\
\text { Altos de Chiapas. El Colegio de la Frontera Sur. Bases de datos SNIB-CONABIO proyecto No. } \\
\text { M001. México, D.F. }\end{array}$ & 20 \\
\hline P140 & P140 & $\begin{array}{l}\text { Gutiérrez Garduño, M. V. 1999. Sistematización del Herbario Nacional Forestal Biól. Luciano } \\
\text { Vela Gálvez. Secretaría de Agricultura, Ganadería y Desarrollo Rural. Instituto Nacional de } \\
\text { Investigaciones Forestales Agrícolas y Pecuarias. }\end{array}$ & 7 \\
\hline
\end{tabular}



SNIB-CONABIO Proyectos No. DC002, BA006 y U009. México. D. F.

Q017 Q017 Rzedowski, J. y S. Zamudio. 2001. Etapa final de la captura y catalogación del Herbario del Instituto de Ecología, AC, Centro Regional del Bajío.

R031 R031 Diego Pérez, N. y M. Martínez Gordillo. 2001. Base de datos del Municipio General Heliodoro Castillo, Guerrero (120. Sierra Madre del Sur). Universidad Nacional Autónoma de México. Facultad de Ciencias. Bases de datos SNIB-CONABIO proyecto No. R031. México, D.F.

SI-BMM SI-BMM Gual, D. M.; Rendón, C. A.; Alamilla, F. L.; Cifuentes, R. P. \& Lozano, R. A. T. 2013. Bosque Mesófilo de Montaña de México. Comisión Nacional para el Conocimiento y Uso de la Biodiversidad.

T015 T015 Dávila Aranda, P. y R. Lira Saade. 2001. La flora útil de dos comunidades indígenas del Valle de Tehuacán-Cuicatlán: Coxcatlán y Zapotitlán de las Salinas, Puebla. Universidad Nacional Autónoma de México. Facultad de Estudios Superiores Iztacala. Bases de datos SNIB2013CONABIO proyectos No. T015, Q014-Flora útil y P091-Flora útil. México, D.F.

U008 E004 L188 Jiménez Ramírez, J, y M. Martínez Gordillo. 2003. Fusión y actualización de las bases de datos del Herbario de la Facultad de Ciencias, UNAM (FCME), Guerrero. Universidad Nacional Autónoma de México. Facultad de Ciencias. Bases de datos SNIB-CONABIO proyectos No. U008, R031Municipio H. Castillo, L188, L092 y E004. México, D.F.

U011 U011 Santana-Michel, F. J., Cuevas Guzmán, R. y Guzmán Hernández, L. 2003. Actualización de la base de datos sobre la flora de la Reserva de la Biósfera Sierra de Manantlán. Jalisco-Colima, México. Universidad de Guadalajara. Centro Universitario de la Costa Sur. Bases de datos SNIB-CONABIO proyectos No. U011 y A007. México, D.F.

U048 U048 Guízar Nolazco, E. 2004. Banco de datos florísticos del Herbario CHAP. Universidad Autónoma Chapingo. División de Ciencias Forestales. 